\title{
The Action of Alkalis on Wool
}

\section{THE SUBDIVISION OF THE COMBINED CYSTINE INTO TWO FRACTIONS DIFFERING IN THEIR RATE AND MODE OF REACTION WITH ALKALIS}

\author{
By W. R. CUTHBERTSON AND H. PHILLIPS, Wool Industries Research Association, \\ Torridon, Headingley, Leeds 6
}

(Received 28 July 1944)

Only $50 \%$ of the disulphide-S of wool will react with $\mathrm{NaHSO}_{3}$ to give thiol and $S$-cysteinesulphonate groups (Elsworth \& Phillips, 1941; Middlebrook \& Phillips, 1942). We have now shown that the disulphide-S of wool can be subdivided into two halves differing in their reaction with alkalis; one-half tends to decompose according to reaction (1), whilst the other half tends to decompose according to reaction (2):

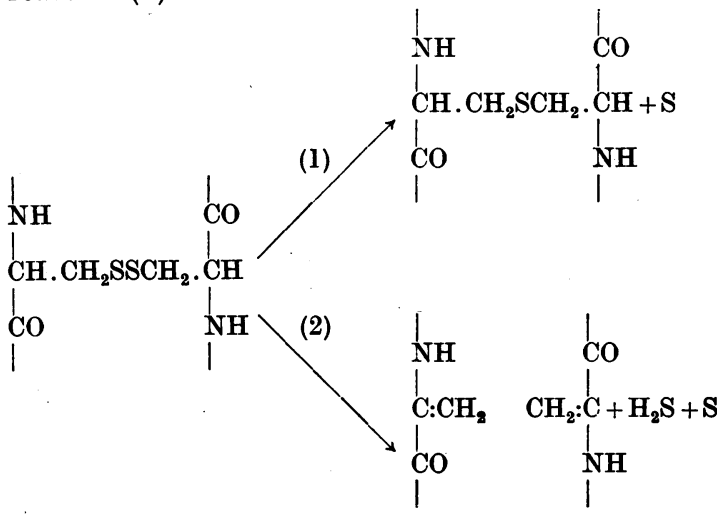

Reaction (1) leads to the formation of combined lanthionine, which was isolated for the first time by Horn, Jones \& Ringel (1941) from wool and other S-containing proteins which had been boiled with dilute $\mathrm{Na}_{2} \mathrm{CO}_{3}$. The combined lanthionine provides thio-ether cross-linkages which Speakman \& Whewell (1936) suggested might be present in wool after treatment with solutions of $\mathrm{NaOH}$. Reaction (2) leads to the formation of combined $\alpha$-amino-acrylic acid in the wool: Bergmann \& Stather (1926) have shown that the alkaline decomposition of the dianhydride of dialanyl cystine follows a similar path.

We have found that most wools contain small amounts of $\mathrm{S}$ which cannot be accounted for either as cystine or methionine-S. We have therefore made an analysis of a root wool, which was undamaged either by light or by the methods by which it was cleaned, in order to confirm that the total-S could be accounted for by cystine and methionine-S (Barritt, 1934 $a$; Bailey, 1937) and hence that virgin wool does not contain lanthionine.
It has been assumed that alkalis hydrolyze and decompose disulphide cross-linkages and that the groupings produced condense with the $\mathrm{NH}_{2}$ groups of opposed side-chains, giving new cross-linkages, such as - SNH- (Speakman, 1933) and - $\mathrm{CH}=\mathrm{N}-$ (Phillips, 1936). We have attempted to obtain chemical evidence to decide whether such reactions take place, in addition to reactions (1) and (2), when wool is boiled with feebly alkaline solutions.

\section{METHODS}

\section{Materials}

Root wool. Wool referred to subsequently in this paper as root wool was prepared as follows. About $2.5 \mathrm{~kg}$. of a greasy, merino 64's Cape wool of $10 \mathrm{~cm}$. staple length were taken, the discoloured locks were rejected and the root ends were cut from the remainder at about $5 \mathrm{~cm}$. from the tips. The root wool $(900 \mathrm{~g}$.) was extracted with benzene at room temperature, dried and carded on a small mechanical card to remove dirt and vegetable matter. Some $460 \mathrm{~g}$. were rinsed in water, then in saponin $(0.1 \%)$ and lastly in water, all at 35-40 . After drying overnight at $40^{\circ}$, it was recarded and gave $437 \mathrm{~g}$. of clean root wool.

Tip wool. Fibre tips, about $2 \mathrm{~cm}$. in length, were cut from the greasy locks. They were cleaned in a similar manner to the root wool.

Fabric wool. This wool was in the form of an unbleached but scoured worsted fabric made from 64-70's wool. Before use in the experiments described, it was extracted first with light petroleum and then with ethanol.

\section{Analytical methods}

S-distribution. The wools were conditioned, i.e. exposed until they reached constant weight in a controlled atmosphere of $21^{\circ}$ and $65 \%$ R.H., before samples were taken for analysis. All analytical results are recorded as percentages of the weight of the anhydrous wool. Total-S on intact wool was determined by a modification of the Benedict-Denis method (Barritt, 1934b); methionine-S was calculated from the $\mathrm{CH}_{3}$ content determined by Baernstein's method (1934). For the determination with the aid of a Spekker absorptiometer of thiol and disulphide-S by Shinohara's methods $(1935 a, b)$, the wool was hydrolyzed $(1 \mathrm{~g} . / 20 \mathrm{ml} .5 \mathrm{~N}-\mathrm{HCl})$ for $4 \mathrm{hr}$., the hydrolysate being filtered through sintered glass. $\mathrm{SO}_{4}^{-}$and $\mathrm{S}$ oxidizable to $\mathrm{SO}_{4}^{-}$by bromine (Br-oxidizable-S) in the filtered hydrolysates were respectively determined by the methods of Mease (1934) and of Blumenthal \& Clarke (1935). 
The pyruvic acid contents of wool hydrolysates. These were determined on the hydrolysates, prepared as described above, by Lu's method (1939). The pyruvic acid arises from the acid hydrolysis (reaction 2), of the combined $\alpha$-amino-acrylic acid (Bergmann \& Delis, 1927). The pyruvic acid content of the hydrolysate of untreated wool is appreciable owing to the acid decomposition of cystine (Elsworth \& Phillips, 1938). For this reason, and also because the amount of pyruvic acid found is sensitive to the method used to heat the wool and the $\mathrm{HCl}$, no great accuracy is claimed for our determinations. The acid hydrolysate of untreated wools contain about $0.3 \%$ pyruvic acid.

The bromine absorptions of wool, methionine and lanthionine. The acid hydrolysate (or solution of amino-acid in $\mathrm{HCl})$ was made up to $100 \mathrm{ml}$. To the hydrolysate $(10 \mathrm{ml}$.) in a stoppered bottle, $0.2 \mathrm{~N}-\mathrm{KBrO}_{3}(10 \mathrm{ml}$.) in $10 \% \mathrm{KBr}$ was added and after $1 \mathrm{hr}$. KI (10 ml. of $10 \%$ solution). The liberated iodine corresponding to the unabsorbed bromine was titrated with $0 \cdot 1 \mathrm{~N}-\mathrm{Na}_{2} \mathrm{~S}_{2} \mathrm{O}_{3}$. Under these conditions, cystine absorbs 10 atoms of $\mathrm{Br}$ per molecule (Plimmer \& Phillips, 1924). It was found that methionine absorbed 3.90 atoms of $\mathrm{Br}$ per molecule in $1 \mathrm{hr}$. and 4.05 in $1 \frac{1}{2} \mathrm{hr}$.; lanthionine absorbed 3.90 atoms in $\frac{1}{2} \mathrm{hr}$., 4.2 atoms in $1 \mathrm{hr}$., and 4.5 in $2 \frac{1}{2} \mathrm{hr}$.

Free lysine-amino-N of intact wools. Rutherford, Harris \& Smith's method (1937) was used. To assist the removal of air from between the wool fibres, a modified reaction chamber was attached to the newer constant volume Van Slyke apparatus. In this chamber, the wool $(0 \cdot 1 \mathrm{~g}$.) was compressed by a glass cylindrical closed vessel containing mercury, supported by indentations made from the outside of the chamber above the lower outlet tube.

Aldehyde groups in intact wools. (a) With semicarbazide. The $\mathrm{KCl}$ precipitated when potassium acetate $(8 \mathrm{~g}$.$) in$ methanol (30 ml.) was added to semicarbazide hydrochloride $(8 \mathrm{~g}$.) in water $(20 \mathrm{ml}$.) was removed by filtration and the filtrate and washings made up to $400 \mathrm{ml}$. with water. The wool ( $1 \cdot 0$ g.) was heated at $40^{\circ}$ for $23 \mathrm{hr}$. with $50 \mathrm{ml}$. of this $2.0 \%$ semicarbazide solution, then rinsed with water $(100 \mathrm{ml}$.) several times daily for 8 days. After squeezing and conditioning, the $\mathrm{N}$ content was determined by Kjeldahl's method. Attempts to determine the $\mathrm{N}$ of semicarbazide by this method confirmed the usually accepted view (Hobson, 1929) that only one-third of the total-N of semicarbazide is returned as $\mathrm{NH}_{3}$ and this pro. portion was not increased by adding either $\mathrm{Zn}$ or $\mathrm{Cu}$ to the $\mathrm{H}_{2} \mathrm{SO}_{4}$ before digestion. When acetophenone semicarbazone was digested with an equal weight of glucose the yield of $\mathrm{NH}_{3}$ was increased to $60 \%$ of the total-N. (b) With pbromophenylhydrazine. A $0.02 \mathrm{M}$ solution was prepared by adding the hydrazine-HCl (3.38 g.) in hot water $(25 \mathrm{ml}$.) to methanol $(20 \mathrm{ml}$.) containing potassium acetate $(1.47 \mathrm{~g}$.). After the addition of hot water $(25 \mathrm{ml}$.), the solution was filtered and the filtrate made up to $750 \mathrm{ml}$. with methanol. The wool (2.0 g.) was heated under reflux for $24 \mathrm{hr}$. with $150 \mathrm{ml}$. of the reagent and rinsed first with methanol and then with water until free from $\mathrm{Cl}$. The $\mathrm{Br}$ content of the wool was determined by the Carius method.

\section{RESULTS •}

\section{The S-distribution of root and tip wools}

Root wool. The S-distribution of the hydrolysates of the root wool is given in Table 1.
Table 1. The S-distribution of root wool

$\begin{array}{ll}\text { S present as: } & (\%) \\ \text { Disulphide } & 2 \cdot 91 \\ \text { Thiol } & 0 \cdot 07 \\ \text { Methionine } & 0 \cdot 12 \\ \text { Sulphate } & 0 \cdot 07 \\ \text { Humin } & 0 \cdot 02 \\ \text { Hydrogen sulphide } & 0 \cdot 01 \\ \text { Sublimed sulphur } & 0 \cdot 01 \\ \text { Br-oxidizable-S } & 0.08 \\ & \mathbf{3 \cdot 2 9} \\ \text { Total sulphur (root wool) } & 3.45\end{array}$

Total-S determinations on the hydrolysates of this wool showed that less than $0 \cdot 10 \% \mathrm{~S}$ was lost during hydrolysis. Determination of the $S$ removed in the humin, or evolved as $\mathrm{H}_{2} \mathrm{~S}$, or deposited as $\mathrm{S}$ on the cooler parts of the flask, showed that such losses could not account for the low $S$ content of the hydrolysates as computed in Table 1 . The S present in the hydrolysates as $\mathrm{Br}$-oxidizable-S increased with the length of time of hydrolysis: a $24 \mathrm{hr}$. hydrolysate contained $0.13 \%$, whereas a $4 \mathrm{hr}$. hydrolysate contained $0.08 \%$.

Experimental errors play a decisive part in assessing the significance of the discrepancy between the $S$ of the hydrolytic products $(3 \cdot 29 \%)$ and the total-S of the whole wool (3.45\%). Mr W. L. Semple has examined statistically the results of 41 of our disulphide-S determinations and 104 determinations of total-S and has estimated the standard error (SE) of a single determination to be 0.074 and 0.038 respectively. The SE of the sum of the constituents (3.29) is approximately 0.080 . The SE of the difference of the two estimates of the total-S $(0 \cdot 16)$ is 0.088 and the ratio of the difference to the $\mathrm{SE}$, known as 'Student's' ' $t$ ', is $\mathbf{1} \cdot \mathbf{8 2}$. From tables a value of ' $t$ ' as great as this will occur due to experimental error more often than 1 in 20 times. Hence we conclude that the results given in Table 1 provide no grounds for assuming that any non-disulphide-S in the form of lanthionine or like compound exists in undamaged wool.

\section{The S-distribution of tip wool}

The sample of tip wool examined was prepared as previously described, but at a different time from the root wool of Table 1 . For this reason, an analysis of the root and tips from the same specimen of wool was made (Table 2).

$\begin{array}{ccc}\text { Table 2. The S-distribution of root and tip } & \text { wools } \\ & \text { Root } & \text { Tip } \\ \text { S present as: } & (\%) & (\%) \\ \text { Disulphide } & 2.99 & \mathbf{2 \cdot 6 6} \\ \text { Thiol } & 0 \cdot 14 & 0 \cdot 15 \\ \text { Methionine } & 0 \cdot 12 & \mathbf{0 . 1 2} \\ \text { Sulphate } & 0.06 & 0 \cdot 10 \\ \text { Br-oxidizable-S } & 0 \cdot 00 & 0 \cdot 02 \\ \text { Total-S } & 3 \cdot 60 & \mathbf{3 . 5 7} \\ \text { Ash (after sulphation) } & 0 \cdot 27 & 0.66\end{array}$


From Table 2 the root wool contained $0.35 \%$ and the tip wool $0.63 \%$ of $S$ which was neither cystine nor methionine-S. If the sulphate-S and $\mathrm{Br}$-oxidizable-S are subtracted from this $S$, we obtain 0.29 and 0.51 as the possible percentages of $S$ which may be present in the two wools as lanthionine-S.

\section{The S-distribution of alkali-treated wools}

Wools treated with buffer solutions of $\mathrm{pH} 8 \cdot 2-10 \cdot 0$. Samples (about 4 g.) of fabric wool, after wetting, were boiled for the times given in Table 3, with borax buffers (500 ml.) of $\mathrm{pH} 8 \cdot 2$, unless otherwise stated. The $\mathrm{pH}$ of the buffer solutions remained unchanged, even after the longest treatment (5 hr.), but they became slightly,turbid and some $\mathrm{H}_{2} \mathrm{~S}$, was evolved. The lengthier treatments caused the wool to become somewhat yellow. The $5 \mathrm{hr}$. treatment was repeated with hourly changes of the buffer (sample 8), and to ascertain whether atmospheric $O$ influenced the reactions, sample 9 was boiled for $5 \mathrm{hr}$. with $\mathrm{O}_{2}$-free buffer in an atmosphere of $\mathrm{N}_{2}$. After treatment, all the wools were rinsed with water. The total-S of the intact wools and the Sdistributions of their hydrolysates are given in Table 3.

Table 3. The S-distribution of wool after boiling with buffers of $\mathrm{pH} 8 \cdot 2-10 \cdot 0$

\begin{tabular}{|c|c|c|c|c|c|}
\hline $\begin{array}{l}\text { No. of } \\
\text { sample }\end{array}$ & $\begin{array}{l}\text { Dura- } \\
\text { tion of } \\
\text { treat- } \\
\text { ment } \\
(\mathrm{hr} .)\end{array}$ & $\begin{array}{c}\text { Thiol-S } \\
(\%)\end{array}$ & $\begin{array}{c}\text { Disul- } \\
\text { phide-S } \\
(\%)\end{array}$ & $\begin{array}{c}\text { Br-oxidiz- } \\
\text { able-S } \\
+\mathrm{SO}_{4}^{-}, \\
\text {as } \mathrm{S} \\
(\%)\end{array}$ & $\begin{array}{c}\text { Total-S } \\
(\%)\end{array}$ \\
\hline 1 & 0 & $0 \cdot 12$ & $2 \cdot 49$ & 0.37 & $\mathbf{3 . 5 3}$ \\
\hline 2 & $\frac{1}{2}$ & 0.12 & $2 \cdot 33$ & $0 \cdot 30$ & 3.39 \\
\hline 3 & 1 & 0.06 & $2 \cdot 00$ & 0.57 & $3 \cdot 41$ \\
\hline 4 & 2 & $0 \cdot 13$ & $1 \cdot 65$ & 0.56 & 3.22 \\
\hline 5 & 3 & $0 \cdot 14$ & 1.49 & 0.59 & $3 \cdot 14$ \\
\hline 6 & 4 & 0.09 & $\mathbf{1 . 3 9}$ & 0.53 & 2.98 \\
\hline 7 & 5 & $0 \cdot 10$ & 1.36 & 0.56 & 2.95 \\
\hline $8^{*}$ & 5 & $0 \cdot 12$ & 1.34 & 0.67 & 2.92 \\
\hline $9 \dagger$ & 5 & 0.12 & 1.31 & 0.53 & 2.86 \\
\hline $10 \dagger \ddagger$ & $\frac{1}{2}$ & 0.09 & 0.67 & $0 \cdot 39$ & $2 \cdot 37$ \\
\hline
\end{tabular}

From the S-distributions given in Table 3, the lanthionine-S contents of the wools can be calculated by subtracting the sum of the $S$ present as methionine-S $(0 \cdot 12 \%)$, sulphate, $\mathrm{Br}$-oxidizable-S, thiol-S and disulphide-S from the total-S. The loss of cystine-S can be calculated by subtracting the sum of the methionine-S, thiol-S and disulphide-S from the total-S of the untreated wool. This involves two assumptions: first, that the untreated wool has not lost any of its virgin $S$ content, and secondly, that when the wool was treated no serious loss of wool substance other than $\mathbf{S}$ took place. Experimentally it was found that sample 9 lost $3.0 \%$ in weight during treatment, about one-third of which was due to loss of $S$; sample 10 lost $5.5 \%$ in weight, of which about one-sixth was $\mathrm{S}$.

In Table 4 the lanthionine-S contents and losses of disulphide-S of the wool samples calculated as described above are given.

Table 4. A comparison between the lanthionine-S and loss of disulphide-S of wools after boiling with buffers of $\mathrm{pH} 8 \cdot 2-10 \cdot 0$

$\begin{array}{ccc}\begin{array}{c}\text { No. of } \\ \text { sample }\end{array} & \begin{array}{c}\text { Lanthionine-S } \\ (\%)\end{array} & \begin{array}{c}\text { Loss of disulphide-S } \\ (\%)\end{array} \\ 1 & 0 \cdot 43 & 0 \cdot 80 \\ 2 & 0 \cdot 52 & 0.96 \\ 3 & 0 \cdot 66 & 1.35 \\ 4 & 0 \cdot 76 & 1.63 \\ 5 & 0 \cdot 80 & 1.78 \\ 6 & 0 \cdot 85 & 1.93 \\ 7 & 0 \cdot 81 & 1.95 \\ 8 & 0 \cdot 67 & 1.97 \\ 9 & 0.78 & 1.98 \\ 10 & 1.10 & 2.65\end{array}$

When the wool is boiled for $4 \mathrm{hr}$., the rate of appearance of lanthionine-S corresponds with the rate of disappearance of cystine-S, but when the boiling is more prolonged or when a buffer of $\mathrm{pH} 10$ is used (sample 10) more cystine-S is lost than would have been expected from the gain in lanthionine-S. This second reaction may therefore be similar to the alkaline decomposition of dialanyl cystine dianhydride (Bergmann \& Stather, 1926), during which both $\mathrm{S}$ and $\mathrm{H}_{2} \mathrm{~S}$ are liberated from each molecule of cystine. The loss of this extra $\mathrm{S}$ does not decrease the amount of lanthionine-S produced.

If some of the cystine decomposes and loses 2 atoms of $S$ per molecule, then the treated wool will contain combined $\alpha$-amino-acrylic acid which would yield pyruvic acid when the wool was hydrolyzed. The pyruvic acid content of the hydrolysate of the untreated wool (sample 1) was $0.28 \%$, that of sample $9,0.42 \%$, thus confirming a small amount of decomposition by reaction (2).

The bromine absorption of the hydrolysate of sample 1 was $0.6038 \mathrm{~g} . / \mathrm{g}$.; that of sample 10 , $0.4525 \mathrm{~g} . / \mathrm{g}$. Sample 1 contained $0.05 \% \mathrm{Br}$-oxidizable-S and sample $10,0 \cdot 17 \%$. On the assumption that all the $S$ in the treated wool has been accounted for in our analyses, it can be calculated that the alteration in bromine absorption due to the change in $\mathrm{S}$ distribution of sample 10 should be $0.1392 \mathrm{~g}$. of $\mathrm{Br} / \mathrm{g}$. The observed difference was $0 \cdot 1513 \mathrm{~g}$. of $\mathrm{Br} / \mathrm{g}$.

Wool treated with solutions of KCN. Samples (about 4 g.) of fabric wool (I) or root wool (II) were immersed for the times given in Table 5 in $1 \%$ solutions of KCN at $66^{\circ}$. One sample of root wool was boiled for $\frac{1}{2} \mathrm{hr}$. in a $0.65 \%$ solution of $\mathrm{KCN}$. In all the experiments the wool samples were treated with 100 times their weight of cyanide solution. The S-distributions of the wools are given in Table 5. 
Table 5. The S-distribution of wool after treatment with solutions of KCN

\begin{tabular}{|c|c|c|c|c|}
\hline $\begin{array}{l}\text { Dura- } \\
\text { tion of } \\
\text { treat- } \\
\text { ment } \\
(\mathrm{hr} .)\end{array}$ & $\begin{array}{c}\text { Thiol-S } \\
(\%)\end{array}$ & $\begin{array}{c}\text { Disul- } \\
\text { phide-S } \\
(\%)\end{array}$ & $\begin{array}{c}\text { Br-oxidiz- } \\
\text { able-S } \\
+\mathrm{SO}_{4}^{=}, \\
\text {as S } \\
(\%)\end{array}$ & $\begin{array}{c}\text { Total-S } \\
(\%)\end{array}$ \\
\hline $\begin{array}{c}0 \\
1 \\
16 \frac{1}{2}\end{array}$ & $\begin{array}{l}0 \cdot 12 \\
0.07 \\
0 \cdot 02\end{array}$ & $\begin{array}{l}2 \cdot 58 \\
2 \cdot 08 \\
0 \cdot 65\end{array}$ & 二 & $\begin{array}{l}3.48 \\
\overline{1.78}\end{array}$ \\
\hline $\begin{array}{c}0 \\
\frac{1}{2} \\
16 \frac{1}{2}\end{array}$ & $\begin{array}{l}0.05 \\
0.01 \\
0.04\end{array}$ & $\begin{array}{l}2.90 \\
0.44 \\
0 \cdot 60\end{array}$ & $\begin{array}{l}0 \cdot 14 \\
0 \cdot 00 \\
0.02\end{array}$ & $\begin{array}{l}3 \cdot 65 \\
2 \cdot 19 \\
2 \cdot 33\end{array}$ \\
\hline
\end{tabular}

After removal of the wool, the KCN solutions gave a faint nitroprusside reaction. They all contained thiocyanate, shown by colorimetric estimation to be roughly equivalent in amount to the $S$ lost by the wool. The analyses (Table 5) show that the acid hydrolysates of treated wools did not contain thiol-S. It is unlikely therefore that these wools before hydrolysis contained thiocyano groups, since by acid hydrolysis they would have been converted into thiol groups and cyanic acid.

After the root wool had been boiled for $\frac{1}{2} \mathrm{hr}$. with $0.65 \% \mathrm{KCN}$, the analyses show that it may have contained $1.62 \%$ lanthionine-S; after $16 \frac{1}{2} \mathrm{hr}$. in $1.0 \% \mathrm{KCN}$ at $66^{\circ}, 1.54 \%$. The disulphide-S losses during these treatments were 3.08 and $2.93 \%$ respectively, corresponding in each case to about twice the lanthionine-S contents. The wool samples decreased 18.7 and $14.6 \%$ respectively in weight during the treatments.

The wool was also treated in $1 \% \mathrm{KCN}$ solution for $19 \mathrm{hr}$. at $62^{\circ}$ and the pyruvic acid contents of the acid hydrolysates of the treated wool and of the $\mathrm{KCN}$ solution in which it was heated were determined. Before hydrolysis the KCN solution did not contain any pyruvic acid, but after hydrolysis it contained $0.04 \%$. The acid hydrolysate of treated wool contained $0 \cdot 20 \%$, making in all $0.24 \%$ pyruvic acid, calculated on the weight of the original wool. Hence no $\alpha$-amino-acrylic acid was formed during the treatment of the wool. This conclusion agrees with the almost complete conversion of the cystine into lanthionine deduced from the $\mathrm{S}$ distributions of the treated wools.

Wools treated with solutions of $\mathrm{NaOH}(a)$ with $0 \cdot 10 \mathrm{~N}$ solutions for increasing lengths of time. Samples $\left(4 \mathrm{~g}\right.$.) of root wool were treated at $20-22^{\circ}$ in $1600 \mathrm{ml}$. of $0.1 \mathrm{~N}-\mathrm{NaOH}$ for the times given in Table 6. The treated wools were rinsed thoroughly, dried and conditioned before analysis; their appearance remained unaltered.

The approximate rate of transformation of cystine into lanthionine during the action of the $0.10 \mathrm{~N}$ $\mathrm{NaOH}$ on the wool can be obtained by calculation and is given in Table 7.
Table 6. The S-distribution of wool after treatment with $0 \cdot 10 \mathrm{~N}-\mathrm{NaOH}$

\begin{tabular}{|c|c|c|c|c|c|}
\hline $\begin{array}{l}\text { Dura- } \\
\text { tion of } \\
\text { treat- } \\
\text { ment } \\
\text { (hr.) }\end{array}$ & $\begin{array}{c}\text { Thiol-S } \\
(\%)\end{array}$ & $\begin{array}{c}\text { Disul- } \\
\text { phide-S } \\
(\%)\end{array}$ & $\begin{array}{c}\text { Sul- } \\
\text { phate-S } \\
(\%)\end{array}$ & $\begin{array}{l}\text { Br-oxidiz- } \\
\text { able-S } \\
(\%)\end{array}$ & $\begin{array}{c}\text { Total-S } \\
(\%)\end{array}$ \\
\hline 0 & $0 \cdot 12$ & 2.95 & 0.06 & 0.02 & $3 \cdot 60$ \\
\hline $2 \frac{1}{2}$ & 0.06 & $2 \cdot 71$ & 0.05 & 0.20 & $3 \cdot 49$ \\
\hline & 0.07 & $2 \cdot 53$ & 0.06 & 0.19 & 3.51 \\
\hline & 0.07 & $2 \cdot 51$ & 0.02 & 0.18 & 3.53 \\
\hline $16 \frac{1}{2}$ & 0.06 & $2 \cdot 12$ & 0.00 & $0 \cdot 16$ & $3 \cdot 29$ \\
\hline 25 & 0.06 & 1.91 & 0.00 & 0.13 & 3.01 \\
\hline $46 \frac{1}{2}$ & 0.04 & 1.83 & 0.00 & 0.12 & 2.89 \\
\hline
\end{tabular}

Table 7. A comparison between the lanthionine-S and the loss of disulphide-S of wools treated with $0 \cdot 10 \mathrm{~N}$ $\mathrm{NaOH}$

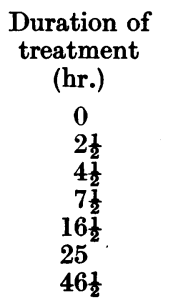

Lanthionine-S
$(\%)$
$0 \cdot 33$
$0 \cdot 35$
$0 \cdot 54$
$0 \cdot 63$
$0 \cdot 83$
$0 \cdot 79$
$0 \cdot 78$

\begin{tabular}{|c|}
\hline $\begin{array}{l}\text { Loss of } \\
\text { lisulphide-S } \\
(\%)\end{array}$ \\
\hline 0.41 \\
\hline 0.71 \\
\hline 0.88 \\
\hline $0 \cdot 83$ \\
\hline $1 \cdot 30$ \\
\hline 1.51 \\
\hline $1 \cdot 61$ \\
\hline
\end{tabular}

Although, for the shorter periods of treatment, twice the lanthionine-S tends. to exceed the disulphide-S loss, the agreement becomes closer with more prolonged treatment. The results bring out clearly that after $16 \frac{1}{2} \mathrm{hr}$. treatment, the $0 \cdot 10 \mathrm{~N}-$ $\mathrm{NaOH}$ has little further action on the wool. When this stage is reached, about $50 \%$ of the cystine-S has been converted into lanthionine-S. It is noteworthy that no Bergmann \& Stather reaction takes place. Mizell \& Harris (1943) have also shown that when wool is treated with $0 \cdot 1 \mathrm{~N}-\mathrm{NaOH}$ at $0^{\circ}$, the $\mathrm{S}$ lost by the wool is approximately equal to half the disulphide-S destroyed and that the treated wool contains lanthionine. (b) With solutions of $\mathrm{NaOH}$ of increasing concentration for $1 \mathrm{hr}$. at $22^{\circ}$. These experiments were made on a 70's wool in the form of knitted fabric. An analysis of the untreated wool is given in Table 8. For the treatments, the samples of wool $(7.5$ g.) were wetted in water and then squeezed until they contained $50 \%$ moisture. The moist wools were then placed for $1 \mathrm{hr}$. in the $\mathrm{NaOH}$ solutions $\left(300 \mathrm{ml}\right.$.) at $22^{\circ}$, allowance being made in strength and volume for the water

Table 8. The S-distribution of wool after treatment with $\mathrm{NaOH}$ solutions of different concentrations

$\begin{array}{cccccc}\begin{array}{c}\text { Nor- } \\ \text { mality } \\ \text { of NaOH }\end{array} & \begin{array}{c}\text { Thiol-S } \\ (\%)\end{array} & \begin{array}{c}\text { Disul- } \\ \text { phide-S } \\ (\%)\end{array} & \begin{array}{c}\text { Sul- } \\ \text { phate-S } \\ (\%)\end{array} & \begin{array}{c}\text { Br-oxidiz- } \\ \text { able-S } \\ (\%)\end{array} & \begin{array}{c}\text { Total-S } \\ (\%)\end{array} \\ 0.0 & 0.03 & 3.09 & 0.07 & 0 \cdot 14 & 3 \cdot 73 \\ 0.10 & 0.04 & 2 \cdot 85 \cdot & 0.04 & 0 \cdot 18 & 3.55 \\ 0.50 & 0.04 & 1.43 & 0.04 & 0.22 & 2 \cdot 85 \\ 1.00 & 0.02 & 0.91 & 0.04 & 0.17 & 2 \cdot 20\end{array}$


the wool contained. After treatment, the wools were rinsed in running water until free from alkali and then dried and conditioned.

Table 9 gives the calculated lanthionine-S contents of these wools and the disulphide-S losses which took place during the treatments.

Table 9. A comparison between the lanthionine-S and the loss of disulphide-S of wools after treatment with $\mathrm{NaOH}$ solutions for $1 \mathrm{hr}$. at $22^{\circ}$

$\begin{array}{ccc}\text { Normality of } & \begin{array}{c}\text { Lanthionine-S } \\ \text { NaOH }\end{array} & \begin{array}{c}\text { Loss of } \\ \text { disulphide-S }\end{array} \\ 0 & (\%) & (\%) \\ 0 \cdot 10 & 0 \cdot 28 & 0 \cdot 49 \\ 0.50 & 0.32 & 0 \cdot 72 \\ 1.00 & 1.00 & 2 \cdot 14 \\ & 0.94 & 2 \cdot 68\end{array}$

Table 9 shows that the lanthionine-S produced agrees with the loss of disulphide-S, until the normality of the $\mathrm{NaOH}$ reaches 1.0: then the loss of disulphide-S exceeds that required to produce the lanthionine-S. It is noteworthy that the lanthionine-S tends to remain at $1.0 \%$, although disulphide-S continues to be destroyed. This suggests that the lanthionine-S is again produced from $50 \%$ of the cystine-S and that when the remaining cystine-S is attacked and decomposed no lanthionine arises. Theoretically $50 \%$ of the cystine-S should yield $0.90 \%$ of lanthionine-S.

When treated with $1 \cdot 0 \mathrm{~N}-\mathrm{NaOH}$ for $1 \mathrm{hr}$. the wool lost $13.2 \%$ in weight. The acid hydrolysate of the treated wool contained $\mathbf{1 . 5 9} \%$ pyruvic acid, whilst the $\mathrm{NaOH}$ solution, after acid hydrolysis, contained $4.15 \%$ calculated on the weight of the wool dissolved. Altogether therefore the pyruvic acid estimated was equivalent to $0.69 \% \mathrm{~S}$ calculated on the weight of the original wool. These results are in agreement with the conclusion that $1.0 \mathrm{~N}-\mathrm{NaOH}$ removes an appreciable amount of cystine-S by the Bergmann \& Stather (1926) reaction.

Wools treated with $0 \cdot 385 \mathrm{~N}-\mathrm{Ba}(\mathrm{OH})_{2}$. Samples $(4 \mathrm{~g}$.) of root wool were treated with $0.385 \mathrm{~N}-\mathrm{Ba}(\mathrm{OH})_{2}$ $\left(200 \mathrm{ml}\right.$.) at $20-22^{\circ}$ for the times given in Table 10. The solutions were renewed every $15 \mathrm{~min}$. in order to minimize the action of any barium sulphide pro-

Table 10. The S-distribution of wool after treatment with $0.385 \mathrm{~N}-\mathrm{Ba}(\mathrm{OH})_{2}$

\begin{tabular}{|c|c|c|c|c|c|}
\hline $\begin{array}{l}\text { Dura- } \\
\text { tion of } \\
\text { treat- } \\
\text { ment } \\
\text { (hr.) }\end{array}$ & $\begin{array}{c}\text { Thiol-S } \\
(\%)\end{array}$ & $\begin{array}{c}\text { Disul- } \\
\text { phide-S } \\
(\%)\end{array}$ & $\begin{array}{c}\text { Sul- } \\
\text { phate-S } \\
(\%)\end{array}$ & $\begin{array}{l}\text { Br-oxidiz- } \\
\text { able-S } \\
(\%)\end{array}$ & $\begin{array}{c}\text { Total-S } \\
(\%)\end{array}$ \\
\hline 0 & 0.12 & $2 \cdot 95$ & 0.06 & 0.02 & 3.60 \\
\hline$\frac{1}{4}$ & 0.07 & 1.78 & 0.03 & $0 \cdot 37$ & $3 \cdot 15$ \\
\hline & 0.06 & $1 \cdot 05$ & 0.07 & $0 \cdot 26$ & $2 \cdot 50$ \\
\hline$\frac{4}{1}$ & 0.04 & $0 \cdot 67$ & $0 \cdot 15$ & $0 \cdot 14$ & $2 \cdot 17$ \\
\hline & 0.03 & 0.52 & $0 \cdot 15$ & $0 \cdot 16$ & 1.91 \\
\hline 4 & 0.00 & 0.42 & 0.03 & 0.15 & 1.63 \\
\hline 6 & 0.00 & 0.34 & 0.12 & 0.10 & 1.64 \\
\hline
\end{tabular}

duced. After treatment, the wools were rinsed in $0.01 \mathrm{~N}-\mathrm{HCl}$ and then in running water over a period of 2 days. They were dried and conditioned before analysis. The treated wools became weaker and yellower with increasing time of treatment.

Table 11. A comparison between the lanthionine-S and the loss of disulphide-S of wool after treatment with $0.385 \mathrm{~N}-\mathrm{Ba}(\mathrm{OH})_{2}$

$\begin{array}{ccc}\begin{array}{c}\text { Duration of } \\ \text { treatment } \\ \text { (hr.) }\end{array} & \begin{array}{c}\text { Lanthionine-S } \\ (\%)\end{array} & \begin{array}{c}\text { Loss of } \\ \text { disulphide-S }\end{array} \\ 0 & 0 \cdot 33 & (\%) \\ \frac{4}{3} & 0.78 & 0 \cdot 41 \\ { }^{3} & 0.94 & 1 \cdot 63 \\ 2 & 1 \cdot 05 & 2 \cdot 37 \\ 4 & 0.93 & 2 \cdot 77 \\ 6 & 0.91 & 2 \cdot 93 \\ 6 & 0.96 & 3 \cdot 06 \\ & & 3 \cdot 14\end{array}$

Table 11 shows that the action of $0.385 \mathrm{~N}-\mathrm{Ba}(\mathrm{OH})_{2}$ on wool is very rapid, the amount of lanthionine produced reaching a maximum in $\frac{3}{4} \mathrm{hr}$. Thereafter a slower reaction takes place in which cystine-S is destroyed without the simultaneous production of lanthionine-S. The amount of lanthionine produced slightly exceeds what would be expected $(0.9 \%)$ if $50 \%$ of the disulphide-S is transformed into lanthionine-S, due probably to the fact that during the more prolonged treatments the wool passes into solution.

It was found that when treated for $2 \mathrm{hr}$. with $0.385 \mathrm{~N}-\mathrm{Ba}(\mathrm{OH})_{2}$, the wool lost $5.2 \%$ in weight. The pyruvic acid content of the hydrolysate of this wool was $1.40 \%$ (equivalent to $0.5 \% \mathrm{~S}$ calculated on the weight of the treated wool), which confirms the occurrence of cystine decomposition by the Bergmann \& Stather mechanism (1926). The treated wool and the $\mathrm{Ba}(\mathrm{OH})_{2}$ solution on acid hydrolysis gave in all $1.54 \%$ pyruvic acid (calculated on the weight of the untreated wool), equivalent to $0.56 \% \mathrm{~S}$.

Wool boiled with $2 \% \mathrm{Na}_{2} \mathrm{CO}_{3}$ solution. Fabric wool (9 g.) was boiled for $1 \mathrm{hr}$. in $2 \% \mathrm{Na}_{2} \mathrm{CO}_{3}$ (135 ml.), these conditions being similar to those employed by Horn et al. (1941). After treatment, the S-distribution of the wool was thiol-S, 0.04; disulphide-S, 0.38; sulphate-S, 0.09 ; Br-oxidizable-S, 0.28; total-S, $2.37 \%$. The S-distribution of the untreated wool was thiol-S, 0.05; disulphide-S, 2.90; sulphate-S, 0.09 ; Br-oxidizable-S, 0.03; total-S, 3.65\%. From this data, it can be calculated that $3.11 \%$ of disulphide-S was decomposed and led to the formation of $1.46 \%$ lanthionine-S. The lanthionine-S is, however, expressed as a percentage of the treated wool, which lost $29 \%$ in weight during the treatment. Calculated on the weight of the original wool the lanthionine-S is therefore $1.02 \%$. At the end of the treatment, the $\mathrm{Na}_{2} \mathrm{CO}_{3}$ solution was free from 
thiol and disulphide-S and after acid hydrolysis the dissolved wool yielded $1.93 \%$ pyruvic acid. On acid hydrolysis the intact wool yielded $0.56 \%$ of pyruvic acid so that, in all, $1.06 \%$ pyruvic acid (calculated on the weight of the untreated wool) was obtained. This is equivalent to $0.38 \% \mathrm{~S}$. The amount of lanthionine produced appears to exceed that expected by the decomposition of half the cystine-S, but the observed excess may be too small to justify the conclusion that boiling $\mathrm{Na}_{2} \mathrm{CO}_{3}$ produces lanthionine from both of the main fractions of the disulphide-S of wool.

\section{The isolation of meso- and dl-lanthionine from alkali-treated wools}

After treatment, as described below, the wools were rinsed in water and then hydrolyzed for $24 \mathrm{hr}$. in $5 \mathrm{~N}-\mathrm{HCl}$. The charcoal-decolorized hydrolysates were concentrated in vacuo, dissolved in ethanol and the lanthionine then precipitated by the addition of pyridine (Horn et al. 1941). The more thoroughly concentrated hydrolysates were not completely soluble in ethanol, the insoluble portion containing much mesolanthionine. The crude lanthionines were purified by recrystallization from water and then from dilute $\mathrm{NH}_{3}$. Cold filtration through charcoal removed the reddish precipitates (ferric hydroxide) from the ammoniacal solutions. Attempts were made to precipitate the lanthionine from the concentrated hydrolysates by adjusting them to $\mathrm{pH} 5$ with $\mathrm{NaOH}, \mathrm{NaHSO}_{3}$ being added to convert the cystine into cysteine and sodium $S$-cysteinesulphonate. By this means, mixtures of lanthionine $(25 \%)$ and tyrosine (75\%) were precipitated. Possibly the precipitation of tyrosine at $\mathrm{pH}$ 2-3 followed by the application of the above procedure would have given purer products. The recrystallization of lanthionine-cystine mixtures from 4 to $10 \%$ solutions of $\mathrm{NaHSO}_{3}$ was found to remove the bulk of the cystine.

(a) $\mathrm{pH}$ 8-treated wool. Scoured and benzene-extracted merino wool was boiled for $1 \frac{1}{2} \mathrm{hr}$. in about 40 times its weight of a borate buffer of $\mathrm{pH} 8.2$. The wool lost $0.2 \% \mathrm{~S}$ and from its S-distribution was shown to contain $1.02 \%$ lanthionine-S. The hydrolysate from $136 \mathrm{~g}$. (conditioned weight) of the treated wool gave on ethanol-pyridine precipitation $2.76 \mathrm{~g}$. of a creamy white mixture, which from its $\mathrm{Br}$ absorption and cystine content was calculated to contain $\mathbf{0 . 3 5} \mathrm{g}$. lanthionine. The filtrate after concentration gave $0.90 \mathrm{~g}$. of a white mixture containing $0.32 \mathrm{~g}$. of lanthionine. These two precipitates thus contained $0.67 \mathrm{~g}$. lanthionine, representing a possible yield of $8.6 \%$ calculated on the lanthionine-S content of the treated wool.

Trituration of these mixtures with $\mathrm{NaHSO}_{3}$ solution left an insoluble portion which was reprecipitated from its solution in $\mathrm{HCl}$ by the addition of $\mathrm{NaAc}$ and $\mathrm{NaHSO}_{3}$. By this means $0.34 \mathrm{~g}$. of pure mesolanthionine, m.p. $304^{\circ}$, was isolated.

(b) $\mathrm{pH}$ 10-treated wool. A scoured, benzene-extracted merino wool was boiled for $35 \mathrm{~min}$. in about 40 times its weight of a borate buffer of $\mathrm{pH} 10$. When diluted with ethanol, the concentrated hydrolysate from $140 \mathrm{~g}$. of the treated and conditioned wool gave a white precipitate, m.p. $295-305^{\circ}$, which consisted of almost pure mesolanthionine. On the addition of pyridine, the mother liquor yielded $0.97 \mathrm{~g}$. of crude mesolanthionine, which after re- crystallization from dilute $\mathrm{NH}_{3}$ had m.p. $306^{\circ}$. Found: $\mathrm{C}, 34 \cdot 6 ; \mathrm{H}, 5 \cdot 8 ; \mathrm{N}, 13 \cdot 4 ; \mathrm{S}, 15 \cdot 8 \% . \mathrm{C}_{6} \mathrm{H}_{12} \mathrm{O}_{4} \mathrm{~N}_{2} \mathrm{~S}$ requires: C, 34.6; H, 5.8; N, 13.5; S, 15.4\%.

The extract prepared by washing the impure ethanolprecipitated mesolanthionine with $4 \% \mathrm{NaHSO}_{3}$ solution deposited a brownish (iron discoloured) precipitate. This was extracted with dilute $\mathrm{NH}_{3}$ and the extract concentrated in vacuo over $\mathrm{H}_{2} \mathrm{SO}_{4}$. After some yellowish matter $(0 \cdot 10 \mathrm{~g}$.) had been deposited and removed, two successive crops $(0.07 \mathrm{~g}$. in all $)$ of white crystalline nodules were formed which by recrystallization from $\mathrm{NH}_{3}$ were obtained as soft, silky, elongated hexagons, m.p. 290-292 ${ }^{\circ}$ They were similar in appearance to the $d l$-lanthionine, m.p. 286-292 ${ }^{\circ}$, synthesized by Brown \& du Vigneaud (1941). Found: C, 34.7; $\mathrm{H}, 5 \cdot 8 ; \mathrm{N}, 13 \cdot 6 ; \mathrm{S}, 15 \cdot 7 \%$. This lanthionine was optically inactive to 5893 in $10 \% \mathrm{NaOH}(c, 0.875 ; c, 0.5)$. The presence of some excess of either optically active isomer may have escaped detection, since the optically active forms of lanthionine synthesized by Brown \& du Vigneaud (1941) had only $[\alpha]_{5893} \pm 8^{\circ}$ under similar conditions. Horn, Jones \& Ringel (1942) isolated $d l$-lanthionine, m.p. 283-284 ${ }^{\circ}$, from $\mathrm{Na}_{2} \mathrm{CO}_{3}$-treated wool.

In all, $2 \cdot 2 \mathrm{~g}$. of mesolanthionine and $0 \cdot 1 \mathrm{~g}$. of the racemate were isolated from the hydrolysate. By calculation the treated wool contained $11 \cdot 1 \mathrm{~g}$. lanthionine, so that about $20 \%$ was isolated. An exhaustive search was made for other organic S compounds besides cystine and lanthionine. Besides the use of the technique of Horn et al. (1941), attempts were made to free the hydrolysates of alkalitreated wools from cystine by precipitating it as cysteine cuprous mercaptide. Such separations were followed analytically by determinations of cystine, cysteine and of bromine absorptions. No indication by any of these methods of the presence of $S$ compounds other than cystine and lanthionine was obtained and it is considered improbable that if present they could have formed more than $3 \%$ of the organic-S-containing fraction of the hydrolysate.

(c) From wool after treatment with a $1 \%$ solution of $\mathrm{KCN}$. Conditioned wool fabric ( $150 \mathrm{~g}$.) was heated for $16 \frac{1}{2} \mathrm{hr}$. with 31 . of $1 \% \mathrm{KCN}$ solution at $66^{\circ}$. The total-S decreased from 3.65 to $2 \cdot 43 \%$ and the S-distribution showed it to contain $1.43 \%$ of lanthionine-S. The hydrolysate from $125 \mathrm{~g}$. of the conditioned, treated wool yielded about $5 \mathrm{~g}$. of precipitate with ethanol-pyridine. From this precipitate $0.84 \mathrm{~g}$. of pure mesolanthionine, m.p. $300^{\circ}$, was isolated. Found: N, 13.7 ; calc. $13.5 \%$. By calculation the treated wool contained $10.8 \mathrm{~g}$. lanthionine; that isolated pure was $7 \cdot 8 \%$ of the total.

\section{Attempts to isolate $\mathrm{Br}$-oxidizable-S from the hydrolysates of alkali-treated wools}

If wool reacts with alkaline solutions as indicated by equations (1) and (2), it would be expected that the Br-oxidizable-S found in wool hydrolysates would be elementary $S$. The amount found might also be expected to depend on the alkalinity of the solution with which the wool is treated, since $S$ is dissolved by alkalis. The recorded analyses of the alkali-treated wools agree with this conclusion, the pH 8.2-treated wools containing the highest percentages of S. Mizell \& Harris (1943) also concluded that the reaction of $\mathrm{NaOH}$ with this elementary $\mathrm{S}$ 
explained the abnormal base-binding capacity of alkali-treated wool.

Experiments designed to prove that this $\mathrm{Br}$ oxidizable-S was elementary $S$ gave inconclusive results. For example, a wool which had been boiled with a borax buffer of $\mathrm{pH} 10$ was extracted with chloroform for $2 \mathrm{hr}$. The extract on evaporation gave a residue which after oxidation with $\mathrm{HNO}_{3}$ contained only $0.05 \% \mathrm{~S}_{\text {as }} \mathrm{SO}_{4}$ (calculated on the weight of the wool extracted), although the hydrolysate of the same wool contained $0.17 \%$ of Br-oxidizable-S. The colorimetric test of Sommer (1940) also gave negative results, although it gave positive results with a solution of gelatin to which a trace of elementary $S$ had been added and with a wool hydrolysate in which a trace of colloidal $\mathrm{S}$ had been produced by reaction between $\mathrm{SO}_{2}$ and $\mathrm{H}_{2} \mathrm{~S}$. A pH 8treated wool was extracted with hot pyridine and the extract was warmed with a little $\mathrm{NaHCO}_{3}$ solution. No coloration was produced, although 1 part of $S$ in 300,000 would have given a blue coloration. Similarly, no eoloration was given by the pyridine-extract of the paste obtained by neutralizing the concentrated hydrolysate of a $\mathrm{pH} 8$. treated wool with $\mathrm{CaCO}_{3}$. Attempts were made to isolate elementary $\mathrm{S}$ from the concentrated hydrolysates from about $160 \mathrm{~g}$. of $\mathrm{pH} 8$ - and $\mathrm{pH} 10$-treated wools, but the quantities isolated and recrystallized did not exceed $100 \mathrm{mg}$.

Treatment of the wools with boiling $0 \cdot 1 \mathrm{~N} \cdot \mathrm{HCl}$ did not make this $\mathrm{Br}$-oxidizable-S easier to extract. A pH 8-treated wool was boiled for $2 \mathrm{hr}$. with acid: no volatile S-compounds were detected and no elementary $S$ was obtained when the wool was extracted with chloroform.

Elementary $\mathrm{S}$ was, however, isolated from a buffer in which wool had been boiled. The yellow solution obtained by boiling wool (22 g.) with borax buffer of $\mathrm{pH} \mathrm{9.7} \mathrm{(1500} \mathrm{ml.)} \mathrm{was} \mathrm{cooled} \mathrm{and} \mathrm{acidified} \mathrm{with}$ $\mathrm{HCl}$. A dirty white precipitate of $\mathrm{S}$ formed, but no $\mathrm{H}_{2} \mathrm{~S}$ was liberated even when the mixture was concentrated. Extraction of the concentrated mixture with chloroform gave $25 \mathrm{mg}$. $\mathrm{S}$, estimated as $\mathrm{SO}_{4}$, although analysis of the wool showed that it had lost $200 \mathrm{mg}$. S.

$S$ liberated during the alkaline decomposition of wool may be firmly held in the fibres and may be difficult to isolate from their acid hydrolysates. On the other hand, it is possible that $S$ leaving the wool is initially in the form of a simple, reactive inorganic compound (e.g. HSOH), which may not decompose quantitatively to elementary $\mathrm{S}$, but may yield more complex inorganic compounds by condensation.

The determination of the thiol, terminal $\mathrm{NH}_{2}$ groups, ketonic and aldehydic groups in alkali-treated wools

A weakness underlying the preceding discussions of the analytical results is that the amounts of
lanthionine-S in the treated wools was not determined directly and consequently includes any $S$ that may be present which is not determined either as cystine, cysteine, methionine, sulphate or $\mathrm{Br}$-oxidizable-S. For example, the $\mathrm{S}$ of the - $\mathrm{SNH}-$ cross-linkages which may be formed during the treatment of wool with alkalis (Speakman, -1933) may have been returned as lanthionine-S. Similarly, the formation of - $\mathrm{SNH}-$ and $-\mathrm{N}=\mathrm{CH}$ - crosslinkages (Phillips, 1936) should leave free thiol groups in the wools which we have not found in their acid hydrolysates. We have, therefore, confirmed the accuracy of the methods by which we have determined the thiol-S in the hydrolysates of alkali-treated wools and have examined the intact wools for the presence of aldehyde groups and to detect the possible disappearance of terminal $\mathrm{NH}_{2}$ groups owing to the formation of - $\mathrm{SNH}-$ crosslinkages.

The determination of thiol groups in alkali-treated wools. Speakman (1936) has shown that intact alkali-treated wools will liberate $\mathrm{N}_{2}$ from a solution of sodium azide in $0.1 \mathrm{~N}$-iodine and has suggested that the reaction indicates the presence of free thiol groups, although Feigl (1931), who discovered this reagent, has shown that it is decomposed by other divalent $S$ compounds. Our analyses of wools before and after treatment with alkalis do not support Speakman's conclusion.

Our failure to detect thiol groups in the expected amounts may, however, have been due to the presence of pyruvic acid and possibly aldehydic compounds in the acid hydrolysates of the wools. Such compounds would condense with thiol groups and so vitiate the determinations. To test this we have added solutions of pyruvic acid and of aldehydes to $2 \mathrm{ml}$. 0.0062 M-cysteine with the usual Shinohara reagents and, as shown in Table 12, have varied the time elapsing between bringing the solutions to $\mathrm{pH} 5$ and the addition of the phosphotungstic

\section{Table 12. The influence of pyruvic acid, formaldehyde} and acetaldehyde on the estimation of cysteine

$\begin{array}{ccc}\begin{array}{c}\text { Concentration of solution } \\ \text { of pyruvic acid } \\ \text { or aldehyde }\end{array} & \begin{array}{c}\text { Time elapsing } \\ \text { before addition } \\ \text { of phospho- } \\ \text { tungstic. acid }\end{array} & \begin{array}{c}\text { Percentage } \\ \text { of maximum } \\ \text { possible colour } \\ \text { developed }\end{array} \\ 0.02 \text { M-Pyruvic acid } & 5 \mathrm{~min} . & 98.5 \\ & 4.5 \mathrm{hr} . & 64.5 \\ 0.10 \text { M-Pyruvic acid } & 5 \mathrm{~min} . & 73.7 \\ & 4.5 \mathrm{hr} . & 17.0 \\ 0.013 \text { M-Formaldehyde } & 5 \mathrm{~min} . & 88.3 \\ & 2 \mathrm{hr} . & 25.2 \\ 0.13 \text { M-Formaldehyde } & 5 \mathrm{~min} . & 27.5 \\ & 2 \mathrm{hr} . & 0.0 \\ \text { 0.02 M-Acetaldehyde } & 2 \mathrm{hr} . & 17.0 \\ 0.02 \text { M-Acetaldehyde } & 2 \mathrm{hr} . & 0.0 \\ \text { Cysteine } & 4.5 \mathrm{hr} . & 95.3\end{array}$


reagent. The results confirm the observations of Sullivan \& Hess $(1937 a, b)$ that aldehydes tend to inhibit the reaction between cysteine and phosphotungstic acid, except that we find acetaldehyde has almost the same inhibiting power as formaldehyde.

Since, in our determinations of thiol-S, the phosphotungstic acid was added within 5 min. of bringing the hydrolysate to $\mathrm{pH} \mathrm{5,} \mathrm{large} \mathrm{amounts} \mathrm{of} \mathrm{pyruvic}$ acid or aldehydes would need to be present to mask any appreciable amounts of thiol-S in the hydrolysates of alkali-treated wools.

Another safeguard against obtaining misleading results due to the presence of pyruvic acid or aldehydes was that each thiol determination was followed by the determination of disulphide-S. This involved the addition of sodium bisulphite to the test solutions. Any condensation products of cysteine with pyruvic acid or aldehydes would have been decomposed gradually by the $\mathrm{NaHSO}_{3}$ and the intensity of colour produced by the addition of phosphotungstic acid would have increased considerably as the cysteine was liberated (Middlebrook \& Phillips, 1942). Experimentally it was found that the intensity of the colour remained constant for 6-7 hr. and in $24 \mathrm{hr}$. increased only slightly, a change due to the slow action of the $\mathrm{NaHSO}_{3}$ on the phosphotungstic reagent, and visible also in the mercuric chloride blank.

As a further check, the cysteine plus cystine contents of a wool before and after treatment with alkali were determined by Kassell \& Brand's modification (1938) of Baernstein's method (1936), in which the protein is hydrolyzed and the cystine reduced with hydriodic acid. This acid is likely to decompose any condensation products of cystine with pyruvic acid or aldehydes. By this method, the untreated wool contained $2.53 \%$ cysteine plus cystine-S as against $2.60 \%$ by the colorimetric method. This wool, after boiling with $\mathrm{pH} 10$ buffer for $\frac{1}{2} \mathrm{hr}$., returned $0.87 \%$ cysteine plus cystine-S as against $0.92 \%$ by the colorimetric method.

Harris (1935) and Crowder \& Harris (1936), who were unable to detect cysteine-S in the hydrolysates of alkali-treated wool, attributed their failure to the condensation of the cysteine with aldehyde groups. By hydrolyzing alkali-treated wool with $18 \mathrm{~N}-\mathrm{H}_{2} \mathrm{SO}_{4}$, which they considered would decompose the condensation products, they obtained hydrolysates returning larger amounts of disulphide-S. We have found that the hydrolysates of untreated and alkalitreated wools with $18 \mathrm{~N}-\mathrm{H}_{2} \mathrm{SO}_{4}$ are too highly coloured for the accurate determination of thiol-S, but the disulphide and thiol-S together could be determined after the addition of $\mathrm{NaHSO}_{3}$. The results we obtained did not indicate that $18 \mathrm{~N}-\mathrm{H}_{2} \mathrm{SO}_{4}$ liberates more cysteine. By our usual methods of analysis, a wool before and after boiling for $\frac{1}{2} \mathrm{hr}$. with borax buffer of $\mathrm{pH} 10$ contained respectively
3.16 and $0.98 \%$ disulphide plus thiol-S, whereas after hydrolysis with $18 \mathrm{~N}-\mathrm{H}_{2} \mathrm{SO}_{4}$ the corresponding results were $3 \cdot 14$ and $0.94 \%$.

It thus appears unlikely that thiol groups in the alkali-treated wools we have examined have escaped estimation owing to faulty methods of analysis. To confirm that the methods we have used would estimate the thiol groups in a reduced wool, a sample of wool was immersed for 5 min. at ordinary tem. perature in a $2 \%$ solution of sodium sulphide. Half of the almost gelatinized wool was rinsed with water and the other half with dilute acetic acid and then with water. When dry, the treated wool was stiff and parchment-like, but $0.87 \%$ thiol-S was found in the hydrolysate of the water-rinsed wool and $0.81 \%$ in the hydrolysate of the acid-rinsed wool.

The terminal $\mathrm{NH}_{2}$ groups. (a) Arginine. The untreated wool was found to contain $19 \cdot 4 \%$ arginine-N (calc. on the total-N) by Vickery's method (1940). After this wool had been boiled with a buffer of pH 10 for $\frac{1}{2} \mathrm{hr}$., it contained $19 \cdot 6 \%$ arginine-N. These values are identical and similar to the value $20.2 \%$ found by Vickery (1940) for wool. (b) $\epsilon-\mathrm{NH}_{2}-\mathrm{N}$ of lysine. The untreated wool examined was a 64's Cape merino from which the tips had been removed. Its total-S was $3 \cdot 78 \%$, disulphide-S, $3 \cdot 12 \%$ and sulphate and Br-oxidizable-S, $0 \cdot 17 \%$. A $20 \mathrm{~g}$. sample was boiled for $1 \mathrm{hr}$. in 31 . of borax-boric acid buffer of $\mathrm{pH} 8$; a further $10 \mathrm{~g}$. were boiled for $65 \mathrm{~min}$. with 1.5 l. of a borate buffer of pH 10. Samples of the untreated wool, the pH 8-and pH 10-treated wools were boiled separately with $0 \cdot 1 \mathrm{~N}-\mathrm{HCl}$ ( $5 \mathrm{~g}$./1.) for $2 \mathrm{hr}$. Such acid-treatment will increase the extent to which alkali-set wool fibres will contract when boiled subsequently in a $1 \%$ solution of $\mathrm{NaHSO}_{3}$ (Speakman \& Stoves, 1937), from which it has been assumed (Stoves, 1942) that terminal $\mathrm{NH}_{2}$ groups are liberated from $-\mathrm{CH}=\mathrm{N}-$ cross-linkages.

The rates of evolution of $\mathrm{N}_{2}$ from these wools when treated with nitrous acid were determined and plotted and, on the assumption (Rutherford et al. 1937) that all the $\mathrm{NH}_{2}-\mathrm{N}$ of lysine is liberated within 4 min., extrapolation of the straight portions of these curves gave the percentages of lysine$\mathrm{NH}_{2}-\mathrm{N}$ in the samples (Table 13).

\begin{tabular}{|c|c|}
\hline Nature of treatment & $-\underset{(\%)}{-\mathrm{NH}_{2}-\mathrm{N}}$ \\
\hline $\begin{array}{l}\text { None } \\
0 \cdot 1 \mathrm{~N}-\mathrm{HCl} \\
\mathrm{pH} \text { 8-treatment } \\
\mathrm{pH} \text { 8-treatment, then } 0 \cdot 1 \mathrm{~N}-\mathrm{HCl} \\
\mathrm{pH} \text { 10-treatment } \\
\text { pH 10-treatment, then } 0 \cdot 1 \mathrm{~N}-\mathrm{HCl}\end{array}$ & $\begin{array}{l}0 \cdot 301 \\
0 \cdot 389 \\
0 \cdot 303 \\
0 \cdot 405 \\
0 \cdot 253 \\
0 \cdot 348\end{array}$ \\
\hline
\end{tabular}

Table 13. The lysine amino- $\mathrm{N}$ of wool before and after treatment with boiling buffer solutions of $\mathrm{pH} 8$ and 10 
The value obtained for the untreated wool is of the same order of magnitude as that obtained by Rutherford et al. (1937), namely, 0.316. The pH 8treated wool gives no evidence of loss of $\mathrm{NH}_{2}-\mathrm{N}$, but the pH 10-treated wool shows a definite decrease which is not recovered by acid hydrolysis. This loss of $\mathrm{NH}_{2}-\mathrm{N}$ is small and corresponds to about $0 \cdot 10 \% \mathrm{~S}$ or $\mathbf{0 . 2 0} \%$ disulphide-S, assuming that for each disulphide group one thiol group and one - SNHcross-linkage is formed.

The determination of $\mathrm{CHO}$ groups. Raynes (1926) showed that wool absorbed small amounts of hydroxylamine and semicarbazide, the amounts being determined from the increase in total- $N$. Trotman, Trotman \& Brown (1928) obtained similar results with wool which had been treated with acid solutions of hypochlorite. Race, Rowe, Speakman \& Vickerstaff (1938) showed that root wool absorbed less semicarbazide and $p$-bromóphenylhydrazine than was absorbed by the corresponding tip wool. Samples 1, 2 and 10 (Table 3) were examined by similar methods to find out whether they would absorb these reagents.

The results of the analyses of the untreated and treated wool samples are given in Table 14, together with similar determinations of Race et al. (1938). In order that our determinations can be compared with those of Race et al. (1938), we have assumed, as they have done, that three atoms of $\mathbf{N}$ are obtained in the Kjeldahl method from each molecule of semicarbazide absorbed. Our preliminary investigations show, however, that it is more likely that only one atom of $\mathrm{N}$ is liberated as $\mathrm{NH}_{3}$ from each molecule of semicarbazide, so that the figures given could most likely be trebled to give the amounts of S removed from cystine linkages. Even when this is done, however, the figures obtained do not nearly equal the amounts of $S$ lost by the wool as calculated from the observed fall in their disulphide-S contents.

From Table 14 it will be seen that our tip wool combined with much less phenylhydrazine than did the tip wool of Race et al. (1938). It is possible that our merino wool was less damaged than the coarser wool of Race et al. (1938), since coarse wools are not so well protected by wool grease against the action of light during growth as are the merino wools.

The amounts of phenylhydrazine with which the untreated and pH 8-treated fabric and root wools combined were very small, corresponding to about $0.10 \%$ cystine-S. Further, acid hydrolysis of the $\mathrm{pH}$ 8-treated root wool did not enable it to combine
Table 14. S (\% of 'wool) equivalent to amounts of ketonic reagents with which light-damaged, untreated and alkali-treated wools combine

$\begin{array}{lcccc} & \begin{array}{c}\text { Disul- } \\ \text { phide-S } \\ \text { lost } \\ (\%)\end{array} & \begin{array}{c}\text { Semi- } \\ \text { carbazide }\end{array} & \begin{array}{c}p \text {-Bromo- } \\ \text { phenyl- } \\ \text { hydrazine }\end{array} \\ \text { Tip wool* } & - & 0.35 & 0.43 \\ \text { Root wool* } & - & 0.17 & 0 \cdot 19 \\ \text { Tip wool } \dagger & 0.67 & - & 0 \cdot 23 \\ \text { Acid-treated tip wool } \dagger & - & - & 0.29 \\ \text { Root wool } \dagger & 0.35 & - & 0.18 \\ \text { Acid-treated root wool } \dagger & - & - & 0 \cdot 18\end{array}$

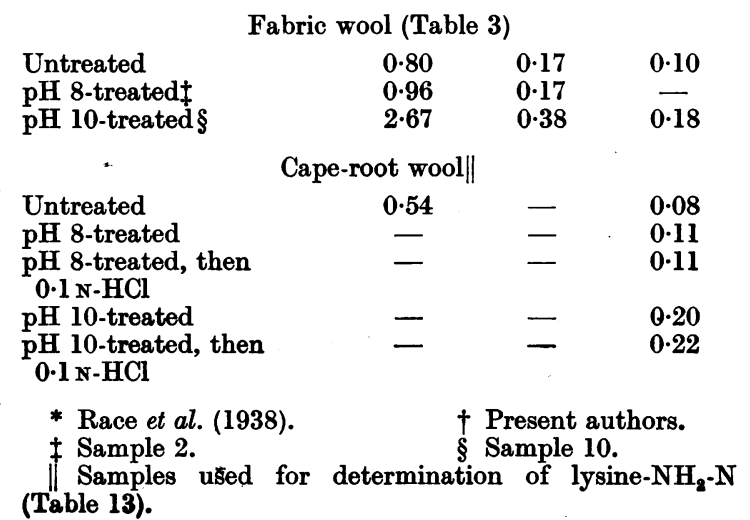

with more phenylhydrazine. The $\mathrm{pH}$ 10-treated fabric and root wools combined with somewhat more phenylhydrazine than did the $\mathrm{pH}$ 8-treated wools, but the amount of combination was not increased by acid hydrolysis.

The results thus provide little evidence that $\mathrm{pH} 8$ treated wools contain free aldehyde or ketonic groups or that they contain - $\mathrm{CH}=\mathrm{N}-$ crosslinkages. In $\mathrm{pH}$ 10-treated wools small numbers of aldehyde or ketonic groups may be present, but they do not condense with $\mathrm{NH}_{2}$ groups. Since pH 10-treated wools contain some combined $\alpha$ amino-acrylic acid, traces of combined pyruvic acid may arise during the reaction of the wool with the $p$-bromophenylhydrazine.

\section{DISCUSSION}

Under a wide variety of conditions, ranging from boiling in buffer of $\mathrm{pH} 8 \cdot 2$ to exposure at room temperatures to $0 \cdot 385 \mathrm{~N}-\mathrm{Ba}(\mathrm{OH})_{2}(\mathrm{pH} 13)$, it appears to be possible to convert only about half the com-

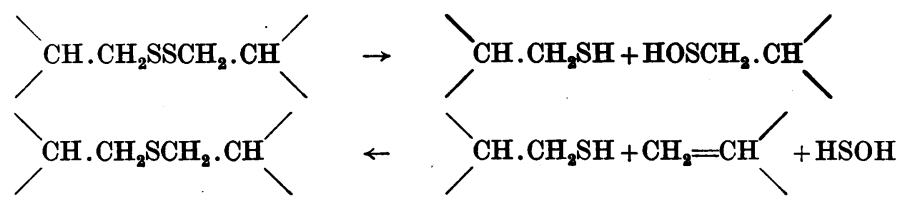


bined cystine of wool into combined lanthionine. The simplest mechanism to propose for the reaction is to assume that the disulphide linkages hydrolyze and the sulphenic acid side-chains produced decompose (see p. 15).

The lanthionine then arises by the condensation of the cysteine side-chain with the methylene group of the combined $\alpha$-amino-acrylic acid. The hypothetical dihydrogen sulphoxide liberated may either

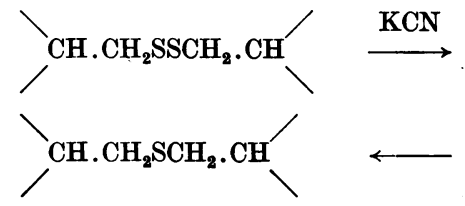

give more complex inorganic $\mathrm{S}$ compounds or decompose into water and $\mathrm{S}$.

The combined $\alpha$-amino-acrylic acid produced by the decomposition of the sulphenic acid group is unlikely to be the source of the pyruvic acid which was found in the acid hydrolysates of the treated wools. If this were so, we should also have found an equivalent amount of cysteine. Since only traces of cysteine were found in the hydrolysates, it appears probable that the conversion of one-half of the cystine into lanthionine occurs quantitatively. This suggests that the formation of the lanthionine is favoured by the molecular structure of keratin in the sense that the cysteine side-chains and the methylene groups are held in close proximity to one another.

It is therefore likely that the other half of the combined cystine of the wool is the source of the pyruvic acid. The absence of cysteine in the hydrolysates also suggests that two $S$ atoms are eliminated from the cystine, giving two molecules of combined $\alpha$-amino-acrylic acid for each. molecule of cystine (reaction 2). Assuming this reaction passes through the hydrolytic stage and that the sulphenic acid grouping decomposes as before, then the absence of lanthionine formation may be due to the instability of the cysteine group which may decompose as postulated by Nicolet (1931), and give rise to the second molecule of $\alpha$-amino-acrylic acid. Further, the decomposition of this cysteine group may be favoured by the absence of structural factors tending to keep it in close proximity to the methylene group. The highest proportion of $\alpha$-amino-acrylic acid (corresponding to $\mathbf{1 \cdot 2 2} \% \mathrm{~S}$ ) was formed in the wool during treatment with $0.385 \mathrm{~N}-\mathrm{Ba}(\mathrm{OH})_{2}$. A small fraction of the cystine-S appears to be very resistant to alkalis.

Almost all the cystine of wool can be converted into lanthionine by solutions of $\mathrm{KCN}$. This reaction, which may pass through the following stages, gives rise to lanthionine from the second as well as the first half of the combined cystine.

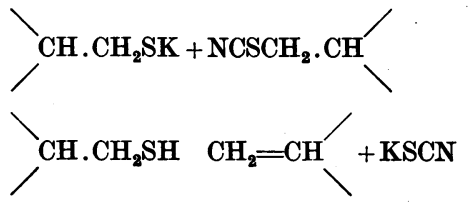

\section{SUMMARY}

1. Only about one-half of the total combined cystine of wool is converted by alkaline solutions into combined lanthionine. The rate of conversion increases with increase of $\mathrm{pH}$ and rise of temperature.

2. When the remaining half of the combined cystine of wool is decomposed by alkaline solutions, each molecule gives rise to two molecules of combined $\alpha$-amino-acrylic acid. The rate of decomposition is slow at $\mathrm{pH} 8$, but increases as the $\mathrm{pH}$ increases and the temperature rises.

3. Nearly all the combined cystine of wool is converted into combined lanthionine when wool is treated with solutions of KCN.

4. An examination of the hydrolysates of alkalitreated wools has failed to provide evidence of the formation of - $\mathrm{SNH}-$ and $-\mathrm{CH}=\mathrm{N}-$ crosslinkages, and intact alkali-treated wools do not contain free aldehydic groups which will combine with $p$-bromophenylhydrazine.

5. It has been confirmed that the total-S of wool, undamaged by light or by detergent solutions, can be accounted for as cystine and methionine sulphur.

The authors are indebted to $\mathrm{Dr} \mathrm{H}$. Lindley for assistance in the determination of the $\mathrm{NH}_{2}-\mathrm{N}$ of intact wools, to Dr L. F. Story for the determinations of pyruvic acid and bromine absorption values, and to $\mathrm{Mr}$ A. B. Gibson for assistance in the general analytical work. Thanks are also due to the Conncil of the Wool Industries Research Association for permission to publish this paper.

\section{REFERENCES}

Baernstein, H. D. (1934). J. biol. Chem. 106, 451. Baernstein, H. D. (1936). J. biol. Chem. 115, 25, 33. Bailey, K. (1937). Biochem. J. 31, 1396.

Barritt, J. (1934a). Biochem. J. 28, 1.

Barritt, J. (1934b). J. Soc. chem. Ind., Lond., 53, 291 т. Bergmann, M. \& Delis, D. (1927). Liebigs Ann. 458, 76.
Bergmann, M. \& Stather, F. (1926). Hoppe-Seyl. Z. 152, 189.

Blumenthal, D. \& Clarke, H. T. (1935). J. biol. Chem. $110,343$.

Brown, G. B. \& du Vigneaud, V. (1941). J. biol. Chem. $140,767$. 
Crowder, J. A. \& Harris, M. (1936). Bur. Stand. J. Res., Wash., 16, 475.

Elsworth, F. F. \& Phillips, H. (1938). J.Text. Inst., Manchr, 29, $219 \mathrm{~T}$.

Elsworth, F. F. \& Phillips, H. (1941). Biochem. J. 35, 135.

Feigl, F. (1931). Qualitative Analyse mit Hilfe von Tupfelreaktionen. Leipzig: Akademische Verlagesellschaft.

Harris, M. (1935). Bur. Stand. J. Res., Wash., 15, 63.

Hobson, R. P. (1929). J. chem. Soc. p. 1384.

Horn, M. J., Jones, D. B. \& Ringel, S. J. (1941). J. biol. Chem. 138, 141.

Horn, M. J., Jones, D. B. \& Ringel, S. J. (1942). J. biol. Chem. 144, 87.

Kassell, B. \& Brand, E. (1938). J. biol. Chem. 125, 145.

Lu, G. D. (1939). Biochem. J. 33, 249.

Mease, R. T. (1934). Bur. Stand. J. Res., Wash., 13, 617.

Middlebrook, W. R. \& Phillips, H. (1942). Biochem. J. 36, 428.

Mizell, L. R. \& Harris, M. (1943). Bur. Stand. J. Res., Wash., 30, 47.

Nicolet, B. H. (1931). J J Amer. chem. Soc. 53, 3066.

Phillips, H. (1936). Nature, Lond., 138, 121.

Plimmer, R. H. A. \& Phillips, H. (1924). Biochem. J. 18, 312.
Race, E., Rowe, F. M., Speakman, J. B. \& Vickerstaff, J. (1938). J. Soc. Dy. .Cot., Bradford, 54, 141.

Raynes, J. L. (1926). J. Text. Inst., Manchr, 17, 379 т.

Rutherford, H. A., Harris, M. \& Smith, A. L. (1937). Bur. Stand. J. Res., Wash., 20, 555.

Shinohara, K. (1935a). J. biol. Chem. 109, 665.

Shinohara, K. (1935b). J. biol. Chem. 112, 671, 683.

Sommer, H. (1940). Industr. Engng Chem. (Anal. ed.), $12,368$.

Speakman, J. B. (1933). Nature, Lond., 132, 930.

Speakman, J. B. (1936). J. Soc. Dy. Col., Bradford, 52, 335.

Speakman, J. B. \& Stoves, J. L. (1937). J. Soc. Dy. Col., Bradford, 53, 236.

Speakman, J. B. \& Whewell, C. S. (1936). J. Soc. Dy. Col., Bradford, 52, 380.

Stoves, J. L. (1942). Trans. Faraday Soc. 38, 254.

Sullivan, M. X. \& Hess, W. C. $(1937 a)$. J. biol. Chem. $120,537$.

Sullivan, M. X. \& Hess, W. C. $(1937 b)$. J. biol. Chem. $122,11$.

Trotman, S. R., Trotman, E. R. \& Brown, J. (1928). J. Soc. chem. Ind., Lond., 47, $4 \mathrm{~T}$.

Vickery, H. B. (1940). J. biol. Chem. 132, 325.

\title{
The Action of Alkalis on Wool
}

\section{THE IDENTITY OF THE LANTHIONINE-FORMING AND BISULPHITE-REACTIVE FRACTIONS OF THE COMBINED CYSTINE OF WOOL}

\author{
By H. LINDLEY AND H. PHILLIPS, Wool Industries Research Association, \\ Torridon, Headingley, Leeds 6
}

(Received 29 September 1944)

In a previous investigation (Cuthbertson \& Phillips, 1945) it was shown that the combined cystine of wool could be divided into two, approximately equal, main fractions differing in their rate and mode of reaction with alkalis. One of these fractions could be converted quantitatively into combined lanthionine (Horn, Jones \& Ringel, 1941), whilst the other tended to decompose in a manner, similar to dialanyl cystine dianhydride (Bergmann \& Stather, 1926), each cystine molecule giving two molecules of combined $\alpha$-aminoacrylic acid:
This reactive half, called fraction $(A+B)$, was further divided (Middlebrook \& Phillips, 1942a) into two subfractions: subfraction $A$, giving waterlabile cysteine and $S$-cysteinesulphonate sidechains which reverted to disulphide-S when the bisulphited wool was rinsed with water, and subfraction $B$, giving cysteine and $S$-cysteinesulphonate side-chains which were stable to water.

In the present investigation we have studied the action of solutions of $\mathrm{NaHSO}_{3}$ on wools which have been boiled with neutral and alkaline buffer solutions and have obtained evidence that it is fraction<smiles>CNC(=O)CC[SH]=S=CC=C1NC(=O)C(CCC(NC)C(C)=O)NC1=O</smiles>

It was also shown (Elsworth \& Phillips, 1941; Middlebrook \& Phillips, 1942 $a$ ) that only one-half of the combined cystine of wool would react with $\mathrm{NaHSO}_{3}$ to give cysteine and $S$-cysteinesulphonate side-chains :
$(A+B)$ of the combined cystine which is converted by alkalis into combined lanthionine. The combined $\alpha$-aminoacrylic acid arises from the alkali decomposition of the second half of the combined cystine, called fraction $(C+D)$, which is not converted into

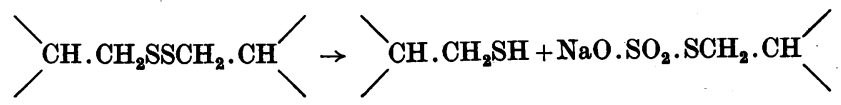

